\title{
NEUROSCIENCE IN DEVELOPING STUDENTS' INTELLECTUAL INTELLIGENCE OF AL-AZHAR ISLAMIC PRIMARY SCHOOL
}

\author{
Susanto' ${ }^{1}$, Ida Royani Munfarokhah' \\ 1,2Institut PTIQ Jakarta \\ 1,2Jalan Batan I No. 2, Lebak Bulus, Cilandak, Jakarta Selatan \\ Email: susanto.kaisar@gmail.com¹, irzafazi@yahoo.com²
}

\begin{abstract}
:
Neuroscience in developing students' intellectual intelligence is crucial to know by teachers. The nervous system structure is an aspect that underlies human actions both from cognitive, affective, and psychomotor aspects. This research aimed to find out information related to neuroscience in developing students' intellectual intelligence of Al-Azhar Islamic Primary School Bumi Serpong Damai. This research was qualitative research using a phenomenological approach. The subjects were one principal as a supporting informant, five teachers, and the students of 1 to 6 grades. The data were analyzed to interpret the data into information so that the data's characteristics or properties can be easily understood and useful to answer problems related to research activities. The results showed that neuroscience could grow the students' attention, develop an active and creative learning model, consider the diversity of brain development of students, develop fun learning stimulation, and create positive emotions.
\end{abstract}

\begin{abstract}
Abstrak:
Ilmu saraf dalam mengembangkan kecerdasan intelektual siswa sangat penting untuk diketahui oleh guru. Struktur sistem saraf merupakan aspek yang mendasari tindakan manusia baik dari aspek kognitif, afektif, dan psikomotorik. Penelitian ini bertujuan untuk mengetahui informasi yang berkaitan dengan ilmu saraf dalam mengembangkan kecerdasan intelektual siswa di Sekolah Dasar Islam Al-Azhar Bumi Serpong Damai. Penelitian ini merupakan penelitian kualitatif dengan pendekatan fenomenologi. Subjek penelitian ini adalah satu kepala sekolah sebagai informan pendukung, lima orang guru, dan siswa kelas 1 sampai 6. Data dianalisis untuk menginterpretasikan data menjadi informasi sehingga sifat atau sifat data dapat dengan mudah dipahami dan berguna untuk menjawab permasalahan yang berkaitan dengan kegiatan penelitian. Hasil penelitian menunjukkan bahwa ilmu saraf dapat menumbuhkan perhatian siswa, mengembangkan model pembelajaran yang aktif dan kreatif, mempertimbangkan keberagaman perkembangan otak siswa, mengembangkan stimulasi belajar yang menyenangkan, dan menciptakan emosi yang positif.
\end{abstract}

\section{Keywords:}

Intellectual Intelligence, Neuroscience, Students

How to Cite: Susanto \& Munfarokhah, I., R. (2020). Neuroscience in Developing Students' Intellectual Intelligence of Al-Azhar Islamic Primary School. Lentera Pendidikan: Jurnal Ilmu Tarbiyah dan Keguruan, 23(2), 328-342. https://doi.org/10.24252/lp.2020v23n2i12. 


\section{INTRODUCTION}

Being a parent is a glorious opportunity that means God has given the trust to have a nursery child. The next parent's job is to take care of the child, keep the child, and to raise their children at their best. For parents, the child is the most valuable treasure. They will give the best love, affection, and attention to their children. The best legacy for the child of his parents is science. One of the ways to create their children to be educated is by studying. If the children's rights are to play, one day when they get older, they will be faced with a variety of choices and difficulties, so the parent's job is to guide and direct the potential that their children have. Education is an effort to devolution of values that will help and as a guide in living life. According to Fadilah (2019) education is guidance or help given by educators to the development of students to reach maturity with the aim that children are capable enough to carry out their own life tasks not with the help of others. Education also improves the fate and civilization of humankind. Education is an essential asset to the nation's progress. Education plays a vital role in determining the quality of its citizens. Because the quality of citizens will determine which way the country will move. Every citizen must attend an education level, whether at an early age, primary education, secondary education, or higher education.

United Nations through the United Nation Educational Scientific and Cultural Organisation established four pillars of education for both the present and the future, namely: (1) learning to know, (2) learning to do, (3) learning to be, (4) learning to live together. The four pillars of education combine the objectives of IQ, EQ, and SQ. According Sukring (2016) to the efforts of educators in developing the intelligence of students according to Islam, it is implementing and internalizing the values of Islamic teachings into the personalities of students which include; a) riyādah, namely: training students to carry out prayers and fasting which can project the intelligence of students (intellect / IQ, heart / EQ, and ruhiyah / SQ), training students to have awareness, tazakur, and tadabur.

Education is the best way to create a new generation. Youth who are intelligent in emotionally and spiritually and not stupid and not retarded in education or aren't aware of developments in every branch of human knowledge. Science is a bridge to a better future to get a better life and bring our nation to compete with other developed countries. Science and technology always be an important part of driving the development of a country. The next generation must be a generation that is entirely mastering science and technology. Information technology that overgrowing also need qualified human resources. This younger generation is expected to be the successor in developing economic progress in the future. Science and technology are the backbones of economic formation that are a significant force in global competition and tools to achieve the nation's prosperity. Armed with this belief, Western and Asian Tiger countries such as Japan, South Korea, and Taiwan have consistently deployed large amounts of funds for their scientists to compete for science and technology. Then there will be innovations implemented by the industry to improve product competitiveness and rake in foreign 
exchange. This process boils down to improving the quality of life and well-being of the nation.

The Holy Qur'an explained that Allah will elevate the position who believe and have knowledge compared than who are just believers without knowledge. Humans were created with all their perfection and Allah SWT gave humans reason to distinguish them from other living creatures by that sense humans are obliged to seek knowledge to not lose in life. Science is like a light that will lead man. Science is a provision for humanity to achieve the success of this world and the Hereafter. The holy Qur'an hates ignorance. The first revelation to come down in the Qur'an is QS. Al-Alaq. This first revelation needs to be an afterthought and reviewed the meaning. Especially the first word of this verse. A word that first barks at the heart of the Prophet. Allah chose this word in the form of motivation on one thing, namely science. And Allah decides one method study of science, which is to read as a method of studying Rabbani.

Islam as a religion carrying out the mission of Rahmatan Lil alamin is very pressing for the people to carry out their mandate to move all his potential because they as the caliph of the earth. The mandate is how people can understand the secrets of the God that are kept behind this universe. That's why humans created as a perfect creature among other beings. God created the brain to think, the heart to be virtuous, and the body to be creative, so humans can understand God's secret behind his creation. The human brain will be fusion when there is sensory stimulation that is the source of science that will be processed by the brain. The brain functions are to save knowledge, add insight, gain new knowledge, understand something with a deeper understanding, and increase knowledge. The brain can change positively when faced with an environment that is given positive stimuli; otherwise, the brain will become negative if not stimulated. Human with his mind be able to create science that will answer all the mysteries behind the universe. Through their heart, human can control and influence the mind to always remember the greatness of God, through the body human trying to implement the work of the brain and heart. This is the importance of education for people. Educators should be able to provide a learning environment that can stimulate students to activate their brains.

Furthermore, if we observed at the words or a question in the holy ' Qur'an. to describe the act of thinking, not only using the word aqala but also Iqra has the basic meaning of collecting, in addition conveying, studying, reading, deep learning, research and know its characteristics. The holy Qur'an also conveys its idea for people to gather various information through observation or Nadzara; or looking abstractly in the sense of thinking and pondering. The Holy Qur'an tells people to "intizar" against the universe, Living beings and lifeless beings with the assurance of the laws of Allah will not change. Tadabbara was contemplating something express and implied. The Holy Qur'an invites people to do research and also reveals the miracles that happen in the universe, as well as trying to utilize all the abundant natural wealth for the welfare of life. Tafakkara means to think on a subject deeply, and the last is Tazakkara the meaning is thinking in develop science. 
Learning is one of students' activities in the learning environment as an early stage of acquiring science. The purpose of learning for students is to obtain the knowledge listed in the optimal learning results according to their intellectual intelligence. In the era of science and technology reform, learning activities must be pursued to the maximum for educational quality because the advance of education has far-reaching implications for human thought in various fields. Every young generation must learn a lot to become educated human beings. The success of an educational objective depends on how students experience the learning process. Unfortunately, in the learning process, there are often some problems, including; many students are sleepy while the learning activities, out of focus, have no motivation to participate in learning, ditched by the time the lesson hours, and low achievement because they do not understand. It occurs because the learning process is not interesting and not enjoyable. The students are not interested in following the learning process or out of focus during the learning. A teacher's job, in this case, is how a teacher can make the learning process more interesting and enjoyable. A teacher must activate the dendrites in the student's brain first before starting the learning process. Thus, teachers get the attention of students just starting learning. Learning is unlikely to occur properly if the brain has not been activated or has to be stimulated first (Nahar, 2016).

Humans have not been optimal in developing their brains in various good ways, such as solving problems and discovering new notions, ideas, creativity, and innovation. The school's educational system ignores the workings of the limbic system as an emotional centre that has not been involved in learning. In contrast, this emotional center is closely related to long-term memory storage. The limbic system's abandonment makes the learning process dead and unattractive; many students are found asleep during the learning process. The utilization of the whole brain in an integrated manner has not been applied effectively in the education system. Neuroscience needs to be used in the learning process because it activates the brain, influences emotions, and improves social skills and motivation. Engaging learners to learn through activities is a fundamental pillar in constructing knowledge, feelings, willpower, and skills.

Neuroscience is a science that learns about the brain and nervous system. The brain regulates the body's entire function, controlling most essential human behaviours such as eating, sleeping, and learning. The brain is responsible for the creation of civilization, art, science, language, etc. Educators generally rarely pay attention to this issue. Abandonment of the limbic system resulted in the death of the learning atmosphere. Systems and objects are not able to run perfectly without a subject. The subject here is an educator who understands the learning that is done. If we more understanding neuroscience, then education goals will be easier to achieve. Education does not provide serious attention to neuroscience, even though it is crucial in maximizing brain function. More than that, neuroscience is a tool to develop a curriculum when viewed from integrating neuroscience development in learning has produced various brain-based learning theories. The brain is a focus on feelings and behaviors. Also, it accepts and undergoes the events. Everything starts and ends in the brain. The 
brain works determine a good human quality of life that includes happiness levels, quality of relationships with others, and success in the profession. The brain regulates the entire function of the body, controlling human behaviors ranging from eating, drinking, sleeping, warming the body, and so on.

To be successful with high intellectual intelligence, we need to give a strong effort to achieve it. Make sure that this dream is not just nonsense. Prove by looking for new inputs useful for us to be a strong foundation in the future. One of the pieces of information is starting with the teacher. One important element in education is the teacher because he/she is responsible for teaching, educating, training, guiding, directing, assessing, and evaluating his/her students in school. So the schools have to have qualified teachers. Finland is the country with the best educational system in the world because of having qualified teachers. Teachers play an important role in developing the potential of students. Teachers, according to Law no. 14. In 2005 "is a professional educator with the primary task of educating, teaching, guiding, directing, training, assessing, and evaluating students on early childhood education informal education, primary education, and secondary education." Teachers are the main culprits in the implementation of education programs in schools and have a vital role to play in achieving the expected educational goals. Teachers can develop students' intelligence potential by creating a fun learning atmosphere that students can enjoy learning. Learning that allows students to play and engage, provide a safe and free atmosphere psychologically, apply non-rigid disciplines, give students the breadth to have their ideas, ideas, or opinions, be able to motivate students to participate actively, and give creative thinking freedom.

The purpose of learning in schools is essential to help students to develop their potential optimally. Therefore, in this case, teachers and schools play a significant role in becoming facilitators for students. As facilitators, teachers must use an active learning approach by encouraging students to find their meaning through real problem-solving for students to construct their knowledge. Active learning will provide sufficient space for the initiative, creativity, and self-reliance following students' physical and psychological talents, interests, and skills. Teachers must have teaching methods that can develop the intellectual intelligence of students. The method is the path that must be taken to make the learners understand the lessons they learned. Methods are essential and must be had by a teacher before entering the classroom. Methods have a significant influence on teaching with methods; learning can be successful or fail. Therefore, methods play an essential role because it is the first foundation to achieve an educational goal and principle of success in learning.

Intellectual factors are one of the factors that play a role in the learning process. With sufficient intellectual ability, one can follow the learning process well. The intellectual ability cannot be separated from the existence of a vital element; the brain. The ability to learn and distract information in humans is an important feature distinguishing between humans and others. Learning ability provides benefits to individuals and communities to place themselves in a cultured being. Learning can change behavior and bring about change in individuals who study and know the attitude 
and skills. The human brain consists of 100-200 billion neuron cells ready to process trillions of information, but generally, only $5-10 \%$ can be used to access information. It's happened because the nerves in the brain are not used to being trained. Our habit of training highly determines the brain's ability to think or reason. It is the same with the muscles we have. Muscle flexibility is caused by regular and accustomed movement. For someone who forces his muscles to work out will feel sore and sick. Similarly, with the brain, a person who is not used to reading books, then his/her eyes will be quickly tired and sleepy. The human brain thinks not only determined by a person's intelligence but also by his habit of maximizing his brain to think and reason.

A smart one who does not think and reason like a sharp knife capable of splitting a can, if exposed to water, it will be blunt for a long time, then it needs care and salting to stay sharp. From this statement, it can be known that the development of human intellectual factors is very closely related to efforts to train the establishment of the brain. If a person is accustomed to maximizing his brain function, then his intellectual ability will develop. This development certainly does not happen by it self but instead requires an ongoing training process. Thus, the learning process should play the role of this intellectual factor to get attention from educators to be developed to the maximum.

Neuroscience is essential to be introduced to the broader community. This new science education is beneficial for the students' development of potential. The more understanding neuroscience-based learning, the educational objectives will be too; otherwise, they do not understand neuroscience learning, then the goal is not to arrive. Philosophically, the nature of education is to form a perfect human being or Insan Kamil to develop all his/her potential or intelligence, both physical, spiritual, and resourceful potential. This research conducted in the elementary school of Islam AL-Azhar BSD because of several reasons, including (1) the school has implemented neuroscience in developing the potential intelligence of students, (2) teachers in this school involve the limbic system as an emotional center in learning, (3) teachers have fun learning methods that can be enjoyed by students and involve activeness and creativity of students in learning. Based on the description, this article focused on neuroscience's role in developing students' intellectual intelligence of al- Azhar Islamic Primary School Bumi Serpong Damai.

\section{RESEARCH METHOD}

The method used in this research was a qualitative approach with a phenomenological design. Qualitative research produces descriptive data in written or oral words from the subject and observed behavior (Sugiyono, 2006). Qualitative research involves data analysis in the form of descriptions. The data is not directly quantified. Qualitative data was done by coding/categorization (Mulyana, 2010). This research sought to transform research objects into forms that can be presented, such as field notes, interviews, conversations, photographs, recordings, and memos (Narbuka \& Achmadi, 2005). The qualitative method is used in research with natural rather than experimental object conditions (Bungin, 2017). Phenomenological studies describe the 
meaning of a life experience for some people about a concept or phenomenon. The people involved are tackling a phenomenon of exploring the consciousness structure of the human life experience. Data collection techniques are a way that researchers use to collect facts and information that can be used as support in research. In this study, the subjects were one principal as a supporting informant, five teachers, and the students of grades 1-6. The students were observed to find neuroscience implementation in developing students' intellectual intelligence at SD Al-Azhar BSD. This research collected data through interviews, observations, and documentation. The data were analyzed to interpret the data into information so that the data's characteristics or properties can be easily understood and useful to answer problems related to research activities.

\section{RESULTS AND DISCUSSION}

The result of data analysis related to neuroscience in developing students' intellectual intelligence of Al-Azhar Islamic Primary Schools presented as follows:

First, neuroscience grows the attention of the students. Teachers at SD Al-Azhar BSD always start learning through the provision of attention. Given the way, the brain works on and off like a computer. Before the learner starts, the teacher should take the student's attention first before beginning the learning to activate the learner's neurons. Attention or attracting students' attention is the action of four mental activity processes that we call learning. How important the role of the brain is to humans because it is all sourced from the brain. Good brain cell tissue is a brain rich in connections due to activity stimuli. Intellectual intelligence can be optimally stimulated through the learning process, then the role of teachers is crucial as a stimulator to students. Students can absorb lessons if they can absorb meaning in the academic material they receive.

Students' ability to learn something is strongly influenced by information processing (perception), beginning with sensory and attention. The information processing model consists of three memory systems interacting with each other. Sensory registers store information for a second or two and play a role in holding information with a high degree of accuracy and selecting information from much-existing information. Short-term memory stores a limited amount of information for approximately 30 seconds. The information is converted into a cipher form, such as a word or phrase. Long term memory has storage power longer than a few minutes to a certain period. Long-term memory consists of memory on how to do things, the internal representation of the surrounding environment and the internal representation of an event experienced directly. Perception begins with sensory and attention. In the absence of both processes, the perception will not occur. In neuroscience learning, the first step that teachers should take is to get attention from students. Synaptic connections between neurons occur a stimulus that enters the brain-one of them by doing appreciation before starting the learning to get the students' attention. Interesting appreciation will attract students' interest to get attention to the teacher and involve emotions, which will bring the lesson into long-term memory. 
The second, neuroscience develops an active and creative learning model. In applying a neuroscience approach, teachers of Al-Azhar Islamic Elementary School stimulate active students and creative thinking. The activeness of learning makes the learners feel a meaningful experience. This experience strengthens the relationship between existing brain cells and forms new neural connections that can help students develop their intellectual potential. In addition, teachers also develop collaborative and cooperative learning models so that students have a meaningful learning experience and can think critically, creatively, innovatively, and solve problems, known as 4C, namely (1) communicative (2) collaborative, (3) critical thinking and problem-solving, (4) creative and innovative. A limbic system in the cerebral cortex serves as a regulator of emotional and emotional memory. Teachers understand the role of emotions in learning is crucial. So All teachers and the ambassador class synergize with each other to realize that learning is fun and involves emotions.

There $80 \%$ of teachers admit the difficulty must exist in conveying learning materials to students due to students' different intellectual, psychological, and other differences. However, not all students only range from 1 to 2 students. Teachers try to condition the classroom, making learning effective. The remaining $20 \%$ said they had no difficulty delivering the material because they were teaching in superior classes. Teachers say that if they have to teach in a class of children who excel in academia have no difficulty conveying materials. Still, in the learning process, the teachers' board always conveys motivation in the form of praise or reward for students to be more passionate about learning. This school's learning environment is very good from the comfortable school conditions for learning, clean location, neatly organized classroom environment, and adequate learning media. The teachers who teach do appreciation that attracts the students' attention to focus on the teacher. The type of question that teachers give also stimulates students to learn, analyze, think critically, communicate, solve problems, work together, form students' character to love learning and make learning a lifestyle love science). Thus the implementation of neuroscience in developing the intellectual intelligence of students goes well in elementary school. AL-Azhar BSD creates a learning environment that is friendly to the child's brain, with a sense of comfort that formed material more easily absorbed and developed intellectual intelligence.

The Third, neuroscience considers the diversity of brain development of students. Diversity is undoubted, so teachers at AL-Azhar BSD in learning always consider the diversity of students' brain development. The application of neuroscience learning considers the level of brain development based on students, at the kindergarten and elementary school level is the age at which brain cells experience rapid growth of $80 \%$.

Stimuli from a variety of activities and a good environment will form good character and stick throughout life. Changes in behaviour and attitudes should be based on changes in thinking first, because the human brain is always developing, and can change for better or for worse. Character education should touch subconscious thoughts that regulate emotional habits, long-term memory, personality, intuition, creativity, perception, and belief and value. The creation and innovation of teachers in applying 
character education will make the learning process in school interesting and meaningful. The achievement of learning outcomes can be balanced between the cognitive, affective, and psychomotor realms. Physical school environment influences students' character building, which covers the arrangement of school facilities and infrastructure, a social environment like friends, teachers, and education staff. Social environment such as friends, teachers, and educational personnel.

Learning is a way to gain knowledge. Learning is often defined as a relatively sedentary change gained from experience and exercise. Learning is always related to changes in the person learning, whether it leads to better things or instead. Learning is an activity business that can prevent changes in the mental or psychic activities that take place active interaction in the environment, resulting in changes in understanding management. It is also a process in which students experience various experiences, resulting in relatively permanent changes to potential behaviour compared to previous behaviours. New visible behaviours indicate these behaviour changes, but changes in cognitive or affective aspects have not or do not appear in real behaviour. Learning in the form of changes in behaviour is often called learning achievements (Suralaga \& Solicha, 2010).

Learning conducted in the classroom will be heavily influenced by the role of teachers in teaching students. One of the teaching obstacles is that teachers have difficulty conveying materials due to differences in intelligence from each learner and other factors. On the other side, the material must be delivered and following the learning targets. On the other hand, not all students can easily understand and absorb the material so that learning is not achieved to the maximum. In learning brain is a tool that processes information that we see listens, or feel into understanding. Information is acceptable and can be processed by the brain so that it can be called by thinking. The brain is a very important factor and cannot be ignored in digesting and understanding matter. The best and the most interesting method if 'doesn't noticed the brain performance will not go on optimally. The human brain like a computer 'can't be used if it is 'doesn't on. The human brain is also unable to absorb incoming information if the brain is not on condition.

According to Andreassen \& Braten (2010), with his concept triune brain says that in its development the brain is divided into three, namely the reptilian brain, the limbic brain, and the neocortex brain. The effectiveness of learning is closely related to three types of human brains that process information differently according to the stimulus provided from the environment. The reptile's brain is also referred to as the keeper's brain. This brain is located at the back. The reptile's brain serves to regulate the movement of reflexes and balance in the human body. This brain that commands us to move in times of danger or protect us from physical harm. The reptile's brain will be active when people feel scared, stressed, threatened with anger or tiredness. When the reptile's brain is active, humans 'can't think in this case, the only instinct that works and immediately moves like the guard guarding the gate. The reptile's brain will react (generally abnormally), after receiving initial information from the mammalian brain 
(which serves as a selector), if the stimulus given from the outside is unpleasant. If we can satisfy the reptile's brain, it will open the flow of information to the next part of the brain. The guard will be satisfied if the surrounding environment is comfortable.

The fourth is developing a fun learning stimulation. Based on the findings of this research, to apply the approach of neuroscience in elementary school. AL-Azhar BSD teachers always develop fun learning. Considering that each student has elements of mammalian or limbic brains that serve as emotional control, it helps maintain hormonal balance such as thirst, hunger, pleasure centres and metabolism. This brain serves to do something involving deep emotions. The third part is the neocortex brain. This brain represents $80 \%$ of our brain; the brain's job is to think, talk, see and create. This brain is a place of intelligence. Neocortex will process information (normally and creatively) also received through the mammalian brain, if the stimulus from its environment is pleasant.

The triune brain is an information channel. The first information enters the reptile's brain. When the reptile's brain is satisfied, it will enter the limbic brain and when the limbic brain is satisfied neocortical brain can process the information in thinking activity. However, suppose the reptile's brain is satisfied. In that case, the information that enters the limbic and neocortex brain is not perfect so that in the process of thinking is also imperfect. This is what makes the material in learning not absorbed perfectly. It is also in line with Abraham Maslow, who is known as a pioneer of the flow of humanistic psychology. Maslow believes that humans are moved to understand and accept themselves wherever possible. His most famous theory is the theory of the hierarchy of needs. According to Maslow, man is motivated to meet his life needs. These needs have a level of order, ranging from the lowest (physiological basis) to the highest (self-actualization). In his psychological theory, the higher need then, the more serious a person's achievement is (Chatib, 2015: 5).

The work of the neocortex brain contributes a lot to the success and activeness of learning. The neocortex brain will process the information correctly and then store it in the memory brain, which is then ready to be recalled when needed during the exam. For the neocortex to work correctly, the teacher in charge of learning is expected to provide pleasant and encouraging stimulation in the learning process.

When students get pleasant stimulation from their environment, there will be various 'high-level touches on the nervous system' that occur in the learners that make them more active and creative mentally and physically, when they smile or laugh the blood flow will smoothly spread throughout the limbs, which makes it more active. Their brains get a blood supply that delivers adequate oxygen (when smiling), making it easier for them to think and process information, both in short-term and long-term memory. Information that enters the memory brain that involves emotions deeply will make it easier for them to recall when such information is needed. This means that students' comfort and enjoyment are very helpful to them in achieving their learning success optimally (Komara, 2016: 3). Suppose a computer needs software to process data. In that case, the brain also needs a stimulus that can be used to link a newly acquired information with information that has been obtained through repetition of information, 
questioning information or disclosing information. Fun in learning is a learning atmosphere that has a pleasant atmosphere so that students focus their attention entirely on learning so that the time of attention is high. Fun learning needs to be understood widely, not just that it's always interspersed with lots of singing jokes or rapturous applause. Fun learning is learning that students can enjoy. Students feel comfortable, safe, and fun. The feeling of fun contains an element of inner motivation that is the impulse of curiosity that is accompanied by an effort to find out something. The meaning of an interesting word that fits this context is fun, excites, shrinks and influences the hazard to pay attention.

The Fifth, neuroscience creates positive emotions. In addition to the approach and methods in learning teachers at Al-Azhar BSD also pay attention to intellectual aspects, emotions, and also motivation. Intellectuals play a role in determining success in the learning process of students, if the students' intellectual intelligence is high then learning process is easier to achieve

Emotions also play an important role in learning. Emotions have a huge effect on the quality and quantity of learning. Positive emotions can speed up the learning process and achieve better learning outcomes; otherwise, negative emotions can slow down learning or stop it altogether. Therefore, successful learning should begin by creating positive emotions in students. To create positive emotions in students can be done in various ways, the delivery is to create a pleasant learning environment and create joy in learning. Excitement doesn't mean creating a boisterous, hurried classroom atmosphere. However, excitement means the rise of understanding and values and happy values in students. In addition, there can also be the development of emotional intelligence in students, namely the ability of a person to manage their emotions healthily concerning others. Motivation also has an important role in learning; a teacher must be able to generate the motivation of students to become learners who love learning. Often encountered students who have high intellectuals but low performance due to their ability not to function optimally. In this case, a motivational role is urgently needed.

The human brain's optimal ability absorbs lessons only the first 20 minutes, after which its ability decreases. Most teachers do not understand this so that it will affect the learning process. They spoke in front of the class for more than 50 minutes while the learners focused only the first 20 minutes. Therefore recommended every 20 minutes of lesson delivery, students are given time to rest, move, stand, or other physical activity because moving provides positive effects for the body, both physical and mental, including cognitive and emotional abilities. Physical activity influences the frontal lobe, an area of the brain for mental concentration and planning. Physical activity can stimulate the release of the hormones neuropinerfin, serotonin, and dopamine that update the brain's nerve cells. Within minutes, students can return to sit receiving lessons with maximum concentration. The motion has positive effects for the body, both physical and mental, including cognitive and emotional abilities. Dopamine is a chemical produced by the middle brain (precisely in substantia nigra and VTA) (Sangkanparan, 2010). Dopamine plays a role in the cognitive process of thinking. This thought process is 
often referred to as the brain's ability to process information. Dopamine also works in motivating humans. This motivation can be useful for biological things, such as eating, hobbies, and motivation to pursue a specific goal. This substance has a large role in the human reward system. Many of the things we have been affected by dopamine, such as memory, sleep, feelings (mood), and attention. Sufficient dopamine levels cause students to be better at developing a new habit and more easily adapt to new environments or new knowledge. Dopamine deficiency can affect attention deficit disorder (ADD); students become less attentive or difficult to concentrate. A gland in the brain produces serotonin, serotonin function for mood regulation, memory processing, sleep, and thought processes. Emotion is an introduction to information. The brain reacts positively to positive emotions and reacts negatively to negative emotions (Darmasyah, 2010).

Indeed, the brain cannot work miraculously without going through the learning process, without input, and without continuous experience throughout life. The energy of information moves from the base of the brain (reptilian brain) through the emotional centre or limbic brain, then passed on to the neocortex's top. Intelligence is the ability to solve problems and creativity that requires a lot of experience and habituation with each learner's relative flying hours. The more often we face complaints of problems, the faster our brains respond to find solutions. However, the more unaccustomed we are to dealing with problems, the slower our brains provide the solution (Salafudin, 2011).

Man under any circumstances is God's masterpiece; the problem is just how the environment provides the right stimulus and opportunity. If the environment, in this case, the teacher offers the right stimulus, then the learner will understand, know, and be smart. Conversely, if the stimulus provided is not appropriate, then the learners are difficult to understand. Cognitive is a person's thinking ability to recognize, analyze something, and ultimately be able to solve his or her problems. Supposedly, this cognitive ability is not limited to the child's ability to do test questions on paper but is more likely to adjust questions in the form of realistic problems with their thinking abilities. Supposedly, this cognitive ability is not limited to the child's ability to do test questions on paper but is more likely to adjust questions in the form of realistic problems with their thinking abilities. Unfortunately, there are still many teachers who give low-level cognitive problems to their students. In low-level cognitive problems, there is no problem element. These types of questions are usually found in the types of multiplechoice questions or multiple choice materials taught. The ability to digest information in the form of knowledge is closely related to the work of the brain. The large brain (cerebrum) is the most prominent front. The process of controlling thinking activities (receiving lesson information) is the frontal lobe and parietal lobe task. Meanwhile, desires and strong tendencies are governed by the frontal lobe. The frontal lobe is fully responsible for thinking, planning, and drafting activities. This section plays an essential role in looking at the future the same as its forward-facing position.

The teaching system has its procedures, known as lesson plans. Teaching plans are not absolute with very flexible validation values following the tendency of pupils' learning styles. None of the lesson plan models is the most correct of the other lesson 
plan models. Everything can be designed according to the student's learning conditions. The lesson plan is not lasting for many years because it is dynamic following the learner's learning style dynamics. It's just that one thing teachers shouldn't do when teaching, which is to teach without a lesson plan.

For teachers to design a lesson plan before teaching is a scientific work, which requires scientific behaviour and is supported by research results. The lesson plan is the first cycle of professional learning and planning that teachers make before teaching. Many teachers at the time of teaching do not first make their teaching plans. Teachers of this model tend to be the origin of teaching so that until the material is finished, the results of the learning process obtained are not maximal. In the development of intellectual intelligence. several approaches can be used including scientific approach, HOTS (higher-order thinking skills), literacy, character education, contextual learning approach, constructivism, deductive, concepts and processes, science, technology, and society. HOTS approach, literacy, and character education, as described above. The contextual approach is set against the backdrop that learners learn more meaningfully by experiencing themselves in a natural environment, not just knowing, remembering, and understanding. Learning is not only target-oriented material mastery; it will fail in equipping students to solve problems in their lives. Thus the learning process takes precedence over the results of learning, so teachers are required to plan learning strategies that are varied with the principle of learning and empowering students not by teaching students. By using this approach, students will experience a thought process that will improve their memory and reasoning-certainly using his intellectual intelligence.

The approach of constructivism is the cornerstone of the contextual approach thinking. Namely that the approach is built by man little by little whose results are expanded through a limited context and not abruptly. The advantage of constructivism theory is that students have the opportunity to actively build knowledge through the process of mutual influence between previous learning and recent learning. Previous learning is associated with recent learning. The assembly is self-built by students. According to constructivism theory, concepts built on a person's cognitive structure will evolve and change when he or she gains new knowledge or experience.

The deductive approach is characterized by exposure to concepts, definitions and terms at the beginning of learning. The deductive approach is based on a thought that the learning process will take place well if the learner has known the area of the problem and the basic concept. Furthermore, the inductive approach has a major feature in information processing is to use data to build concepts or to gain understanding. The data used may be primary data or may also be real cases occurring in the environment.

Traditional learning is learning with a deductive approach, starting with theories and escalating to the application of theory. In the field of science and engineering found efforts to try learning and new topics that present a framework of knowledge, present theories and formulas with little regard for the main knowledge, and less or no related to 
their experience. Learning with a deductive approach emphasizes on teachers transferring information or knowledge.

Learning using a concept approach means that students are guided to understand a language by understanding their concepts. In the learning process, the process of mastering concepts and subconcepts becomes the focus. With some methods, students are guided to understand the concept. In the process approach, the main goal of learning is to develop learners' skills in terms of process skills such as observing, hypothesizing, planning, interpreting, and communicating. The process has been used and developed since the 1984 curriculum (Sesmiarni, 2010). The use of process approaches demands the direct involvement of students in learning activities.

The National Science Teacher Association views the approach of science, technology, and society as teaching and learning of science in the context of human experience. The approach of science, technology, and society is seen as a learning process that always fits the context of the human experience. In this approach, students are invited to increase creativity, scientific attitudes, use science concepts and processes in daily life.

Based on some of the above exposure, it can be concluded that all teachers at SD Islam Al-Azhar have implemented neuroscience in developing the intellectual intelligence of students, this can be seen from the results of interviews, document studies, and observations of students looking enthusiastic, highly motivated, looking happy, and enjoying the learning process. by using the brain's working system, a teacher can understand what happens to the brain of the learner. Neuroscience is useful in recognizing the growth of learners and can be a stimulus to educate and optimize students' ability. Another benefit of knowing neuroscience is being able to know the abnormal behaviour that occurs in students if they experience one of the diseases caused by nervous system disorders. So neuroscience is crucial because neuroscience's main task is to explain human behaviour from the point of view of the activity that occurs in his brain.

\section{CONCLUSION}

Based on the results of the research described above, the implementation of neuroscience in developing the intellectual intelligence of students in Al-Azhar BSD can be summed up as follows; 1 ) to grow the attention of students, 2) to develop an active and creative learning model, 3) to take into account the diversity of brain development of students. 4) to develop fun learning stimulation, and 5) to create positive emotions.

\section{REFERENCES}

Andreassen, R., \& Braten, I. (2010). Examining the Prediction of Reading Comprehension on Different Multiple Choice Tests. Journal of Research in Reading, 33(3). https://doi.org/https://doi.org/10.1111/j.1467-9817.2009.01413.x.

Bungin, B. (2017). Metode Penelitian Kualitatif. Depok: PT Raja Grafindo Persada. 
Chatib, M. (2015). Kelasnya Manusia; Memaksimalkan Fungsi Otak Belajar dengan Manajemen Display Kelas. Bandung: Kaifa Learning.

Darmasyah. (2010). Strategi Pembelajaran Menyenangkan dengan Humor. Jakarta: Bumi Aksara.

Fadilah, R. (2019). Pendidikan Islam Dan Kecerdasan Majemuk (Multiple Intelligence). Al-Irsyad: Jurnal Pendidikan Dan Konseling, 9(2), 61-79. http://jurnal.uinsu.ac.id/index.php/alirsyad/article/downloadSuppFile/6752/1084.

Komara, E. (2016). Belajar dan Pembelajaran Interaktif. Bandung: Refika Aditama.

Mulyana, D. (2010). Metodologi Penelitian Kualitatif (VII). Bandung: Remaja Rosdakarya.

Nahar, N. I. (2016). Penerapan Teori Belajar Behavioristik dalam Proses Pembelajaran. Nusantara, Jurnal Ilmu Pengetahuan Sosial, 1(1). http://jurnal.umtapsel.ac.id/index.php/nusantara/article/view/94.

Narbuka, C., \& Achmadi, A. (2005). Metodologi Penelitian (VII). Jakarta: Bumi Aksara.

Salafudin. (2011). Metode Pembelajaran Aktif ala Rasulullah, Pembelajaran yang Membangkitkan Motivasi (Suatu Kajian Metode Pembelajaran dari Hadist). Jurnal Forum Tarbiyah, 9(2). https://www.neliti.com/id/publications/70252/metodepembelajaran-aktif-ala-rasulullah-pembelajaran-yang-membangkitkan-motivasi.

Sangkanparan, H. (2010). Otak Tengah Memang Dahsyat (Bukti-Bukti Dahsyatnya Otak Tengah). Jakarta: Visimedia.

Sesmiarni, Z. (2010). Model Pembelajaran Ramah Otak dalam Implementasi Kurikulum 2013. Bandar Lampung: Aura Publising.

Sugiyono. (2006). Metode Penelitian Kuantitatif, Kualitatif, dan R\&D. Bandung: Alfabeta.

Sukring. (2016). Pendidik dalam Pengembangan Kecerdasan Peserta Didik (Analisis Perspektif Pendidikan Islam). Tadris: Jurnal Keguruan Dan Ilmu Tarbiyah, 1(1), 69-80.

http://ejournal.radenintan.ac.id/index.php/tadris/article/download/891/764.

Suralaga, F., \& Solicha. (2010). Psikologi Pendidikan. Jakarta: Lemlit UIN Syahid. 